\title{
The Effect of Tarsia Puzzle on Vocabulary Learning in a Primary School Setting
}

\author{
Wan Shafika Omar, Nur Ehsan Mohd Said
}

\begin{abstract}
Vocabulary learning is essential in learning a particular language as its mastery will greatly affect how learners comprehend the language. Young English as Second Language (ESL) learners with limited vocabulary competence are at risk of being left behind in developing the four language skills. Thus, educators across the world play a key role to ensure pedagogical improvement in teaching vocabulary moves at a rapid pace in academia. As an alternative to a conventional vocabulary lesson, this study applied the Puzzle-Based Learning (PBL) to identify its effect on young learners' vocabulary acquisition and their perception of the learning tool in an English as a second language (ESL) context. Tarsia Puzzle incorporates the most basic reasoning to accommodate the young learners' English proficiency. Using a mixed methods research design, the study involved 29 Primary 5 pupils (age 10) from a Malaysian rural school in Lahad Datu, Sabah. Data collection was completed through a set of pre- and post-test as well as a semi-structured interview. Scores from the tests were analysed and compared quantitatively and emerging patterns from the participants' interview were explored. The study suggests that Tarsia puzzle has helped to improve the learners' vocabulary acquisition in addition to collecting positive feedback from them regarding the learning tool.
\end{abstract}

Index Terms - young ESL learners, vocabulary learning, Puzzle-Based Learning (PBL), Tarsia puzzle.

\section{INTRODUCTION}

Words are crucial in developing our train of thoughts [6]. Thus, it is no surprise that vocabulary learning becomes the first step when acquiring a language [2]. Even though it is often of secondary importance in second and foreign language classes [14], vocabulary learning is given great emphasis by the Ministry of Education Malaysia where English is learnt as a second language. The current curriculum - Malaysian Primary Standard Curriculum - is aligned with the Common European Framework of Reference (CEFR) curriculum to formulate a national English language syllabus. An extensive list of vocabulary items to be mastered by pupils is spelt out in curriculum specifications and the list is referred to by teachers throughout the academic year at national schools as the first step in learning English thematically.

In the Malaysian context, most vocabulary learning takes a conventional approach to assist retention. For primary pupils, drilling, mime, gestures and picture-word association are the often employed techniques as they are convenient for classroom management and it allows for a more directed

Wan Shafika Binti Omar, Universiti Kebangsaan Malaysia, 43600 Bangi, Selangor, Malaysia

Nur Ehsan Mohd Said, Faculty of Education, Universiti Kebangsaan Malaysia, 43600, Bangi, Selangor, Malaysia lesson. The risk of developing such routine lies in maintaining pupils' motivation. Employing puzzles during the lesson may provide a different learning experience. It is a multi-faceted activity that could be adapted to suit varying topics and levels of proficiency and it may take different form depending on the type of clues used.

Puzzle, especially crossword has indicated positive effects on student's performance in language learning [17], [19], [43]. Study conducted by Whisenand \& Dunphy[44] revealed that when used as a learning aid, crossword puzzle improves students' performance in an introductory business course to acquire technology-related jargons. It also generated a high level of acceptance among the students. Jaramillo et al.[22] in investigating the efficacy of ICT-integrated crossword puzzle found out that crossword puzzle is an effective tool in developing vocabulary for a specific knowledge area. Orawiwatnakul ${ }^{[36]}$ acknowledged that the use of crossword puzzle effectively increases students' ability in vocabulary retention. His findings suggested that participants enjoy learning using puzzle as it offers engaging environment.

Despite the flourishing studies on puzzle, most of them focus on learners from either a secondary or tertiary education setting. The type of puzzle normally associated with vocabulary learning is also constricted to crossword and its variant. The present study was conducted to fill in the gap in literature, resulting in a focus on young ESL learners instead. It was also specific to Tarsia Puzzle that aimed for use among rural primary schoolers as most of them are still struggling to learn English. Recent studies have urged teachers to reinforce vocabulary teaching in helping ESL learners to learn better. Alqahtani[4] stated that teachers should discover the most appropriate and recent technique in developing learners' vocabulary. Teachers also need to employ the most effective strategies in improving learners' vocabulary retrieval to consolidate their productions skills [3]. In doing so effectively, Cervatiuc[10] suggests that classroom activities need to foster pupils' interest, enhance understanding, drill word retrieval, and help them with deep processing. Adopting the Puzzle-Based Learning (PBL), it is hoped to be effective intervention in teaching vocabulary to examine the effects of Tarsia puzzle on Primary 5 pupils and to explore their perception of the learning tool. Two research questions facilitate the study as what follows: 1) How does Tarsia puzzle affect the teaching of vocabulary among Primary 5 Pupils? and 2) What are the pupil's perception in using Tarsia puzzle to learn vocabulary?. 


\section{ENRICHING VOCABULARY LEARNING EXPERIENCE USING TARSIA PUZZLE}

\section{A. Experiential Learning}

Kolb (1984) believed in transformative experience as the impetus of learning. He presented the Experiential Learning principles as a four-stage learning cycle (Figure 1). Based on the model, effective learning is achieved only if learners "touch all bases" (p.41) in the cycle.

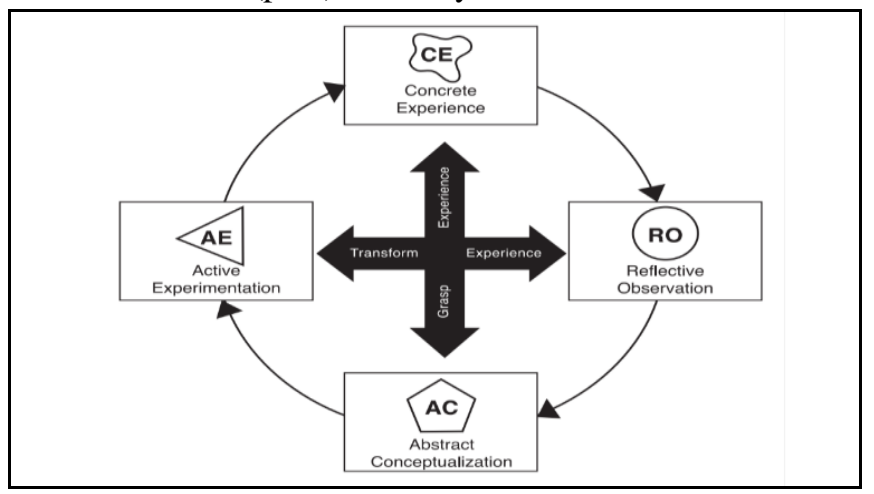

Fig. 1: Adapted from Kolb (1984) Four Stage Learning Model

Kolb and Kolb (2017) perceived learning as an interconnected process. Learners are expected to encounter a tangible experience before learning could take place, regarded as Concrete Experience (CE) stage. They will then review inconsistencies (by making Reflective Observation-RO) between their understanding and the experience. Abstract conceptualization (AC) is achieved once symbolic representation of the experience is attained. Learner then test their knowledge by experimenting (Active experimentation-AE) with the concept formed earlier and dealing with new experience.

This study was conducted based on the stages proposed by Kolb (1984) and Kolb and Kolb (2017). Pupils were first exposed to hands-on experience by assembling the puzzle. The process was then reviewed to draw pupils' attention to the form, meaning and use of the target vocabulary items. Teacher's role was to guide pupils in explaining inconsistencies on certain items such that the irregular form of verbs.

\section{B. Vocabulary Learning}

Barcroft, Sunderman, and Schmitt ${ }^{[5]}$ define vocabulary as the complete repertoire of words in a language. This definition concurs with Willkins ${ }^{,[45]}$ claim that "....without vocabulary nothing can be conveyed" (p.111), connoting the significance of vocabulary as the most rudiment aspect of language. Vocabulary knowledge entails three important aspects namely 1) form, 2) meaning and 3) use as elucidated by Nation [33], [34]. Nation ${ }^{[34]}$ explained that form encompasses the spoken form, written form and word parts. The spoken form focuses more on pronunciation, whereas the written form implied how words are written and spelled. Word part pertains word fragments that have the ability to communicate meaning such as suffix, root word and prefix. Meaning is about people's perception of the word. It may link to certain concepts, referents and association. The last aspect - use - is about how the words are manifested in their grammatical patterns, the collocations that cluster the words together and the constraints in using it (frequency, register). All three aspects were addressed when presenting the vocabularies to the young ESL learners using Tarsia puzzle.

Vocabulary may be divided into two dimensions which are the 1) receptive and 2) productive vocabulary. Receptive vocabulary is defined as familiar lexical words perceived by hearing or seeing [9]. Productive vocabulary on the other hand, are words that learners used effectively in oral and written form [4]. In this research, Tarsia puzzle was used to build productive vocabulary. The research participants were upper primary pupils who are preparing for their national formative assessment at the end of six years of schooling. They will be assessed by the ability to effectively apply word form, use and meaning in a comprehension and writing paper.

Vocabulary acquisition may also take the form of incidental and intentional learning. Researchers have long argued on the efficacy of each modality of vocabulary learning. Incidental learning is the process of learning something unintentionally and may occur while learners are engaged in other learning activities [39], [38].This mode of learning is considered as the naturalistic learning condition. Ahmad $^{[1]}$ proposed that incidental learning offers deeper mental processing and retention. On the contrary, intentional vocabulary learning implies a deliberate way of directing learners' consciousness to learning a word [20]. Hulstijn ${ }^{[21]}$ and Elgort ${ }^{[13]}$ affirmed that incidental learning is more effective than incidental learning. Considering the strength of both modalities, Puzzle-Based Learning (PBL) was employed in this research as it incorporated incidental and intentional learning to maximise retention. Schmitt ${ }^{[39]}$ and Zandieh $^{[44]}$ stated that a proper blend of both learning is crucial in ESL classroom.

\section{Puzzle-Based Learning (PBL)}

$\mathrm{Kim}^{[24]}$ and Farlex ${ }^{[14]}$ offered a parallel perspective in defining puzzle. Kim viewed puzzle as a form of play that needs to be solved. Whereas, Farlex regarded puzzle as a game, toy, or problem that requires ingenuity and often persistence in solving or assembling. Both accentuated problem solving as the element of a puzzle. In the same light, Klymchuk $^{[23]}$ believed that a puzzle is non-routine, out of the box problem presented in an interesting way. To succinctly define puzzle, Becky and Susie ${ }^{[7]}$ described it as any games that promote learning and development of multitude cognitive, motor and social skills.

This study employed Tarsia puzzle as an intervention tool because it incorporates the most basic reasoning ("logical link") to be completed by the young ESL learners, taking into consideration the learner's competency in using English. Tarsia takes the form of a geometric shape 
that is separated into smaller fragments (usually triangle) (see Figure 2). Each side of the smaller fragments contains clues that need to match the other side. Stoten ${ }^{[42]}$ listed three benefits of using the puzzle in teaching: 1) It can be used to enhance comprehension of subject content, 2) It encourages collaborative learning and 3) It can be used to create a competitive environment in the classroom.

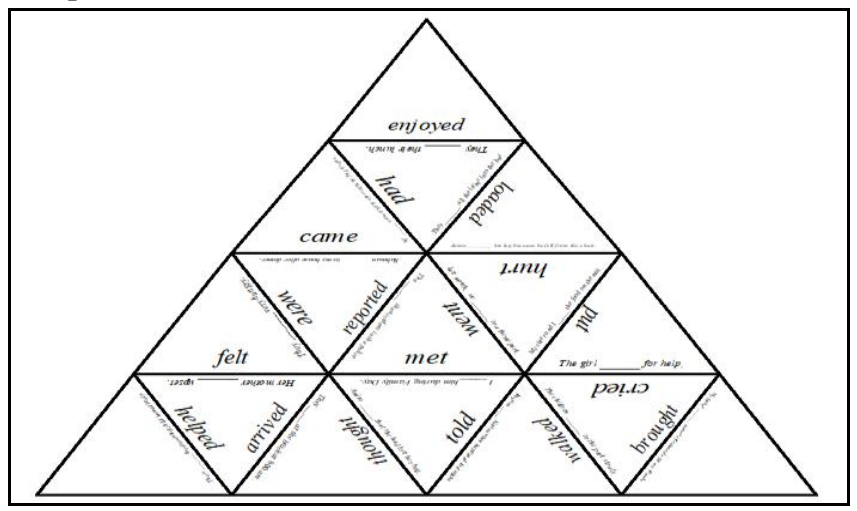

Fig. 2: Example of a complete Tarsia Puzzle

Puzzle-Based Learning (PBL) is an approach typically associated with the learning of Sciences, Mathematics and Technology. PBL serves as a foundation for Problem-Based Learning as it fosters independent reasoning, critical thinking and problem solving skills [31], [32]. This approach has also been found to be effective in reinforcing concepts and vocabulary competence in Medical Sciences [40], [37] as well as boosting learners' motivation and performance in learning Computer Sciences [30], [11]. These studies confirm Jelle ${ }^{[23]}$ and Klymchuk's ${ }^{[25]}$ statement imposing PBL induces positive drive, intrinsically and extrinsically. PBL is far from being underused in the language classroom. Yet, it is never anchored as the main approach in teaching vocabulary. This study was an attempt to vary the use of puzzle in promoting vocabulary competence.

\section{METHODOLOGY}

\section{A. Research Design}

This study took the form of action research. Burns ${ }^{[8]}$ posits that action research is a productive process in extending teaching skill and exploring more about teachers, classrooms and students. It is the most convenient research design to be employed in answering the research questions considering the number of participants involved and specific research context. McNiff ${ }^{[26],[27]}$ describes it as a form of liberating personal or collective enquiry to improve educational values. As such, this study was embarked on to suggest educational improvement in a classroom setting among the young ESL learners.

\section{B. Participants}

29 Primary Five pupils from a rural school in Lahad Datu, Sabah were selected as participants for this research. 13 were male and 16 were female. The participants were selected through a purposive sampling procedure. The young ESL learners were selected as their level of vocabulary acquisition is alarming. They could not perform well in a writing paper and in need of immediate attention as they quickly transition from lower to upper primary pupils. The participants were of mixed-ability and were learners who never practised English at home. However, only 27 pupils' progress were measured. 2 other participants were unable to attend the classes consistently due to health and family matter.

\section{C.Instrument and Data Analysis}

This study was conducted within the course of 4 weeks and the intervention were carried out during extra classes to avoid interference with the syllabus. A pre- and post-test were developed based on the Malaysian national formative assessment for Primary School (UPSR) 2016. Pupils were asked to fill in a table to construct 12 sentences from the stimulus given. It was then marked based on the use of correct verb in past tense form. The pupils' vocabulary knowledge were assessed through the word form, use and meaning in a sentence.

The effects of using Tarsia puzzle were evaluated through pupils' performance in the pre- and post-test. A t-test was conducted to analyse the quantitative data, whereas responses from the interview were coded and put into several emerging themes to answer the research question. Open-ended interview questions in the form of semi-structured were used to gather data from the respondents. During the interview, pupils were asked to listen as to whether the information recorded conforms to their responses. This step was taken to corroborate the data collected and avoid misleading themes in clustering their responses.

\section{FINDINGS}

\section{A. The Effect of Using Tarsia Puzzle in Teaching Vocabulary} among Primary 5 pupils

A dependent sample $t$ test was performed using SPSS Version 2.3 to test whether there had been a statistically significant change in the post-test performance (see Table 1 and 2).

Table 1: Paired Sample Statistics

\begin{tabular}{lrrrr}
\hline & Mean & N & Std. Deviation & Std. Error Mean \\
\hline Pre-test & 5.5926 & 27 & 3.37706 & .64992 \\
Post-test & 6.6296 & 27 & 3.61778 & .69624 \\
\hline
\end{tabular}

Table 2: Paired Sample Test

\begin{tabular}{|c|c|c|c|c|c|c|c|c|}
\hline & \multicolumn{5}{|c|}{ Paired Differences } & \multirow{3}{*}{\multicolumn{2}{|c|}{$\begin{array}{l}\mathrm{d} \\
\mathrm{f}\end{array}$}} & \multirow{3}{*}{$\begin{array}{l}\text { Sig. } \\
(2-\mathrm{t} \\
\text { aile } \\
\text { d) }\end{array}$} \\
\hline & \multirow{2}{*}{$\begin{array}{c}\text { Mea } \\
\mathrm{n}\end{array}$} & \multirow{2}{*}{$\begin{array}{c}\text { Std. } \\
\text { Deviati } \\
\text { on }\end{array}$} & \multirow{2}{*}{$\begin{array}{l}\text { Std. } \\
\text { Error } \\
\text { Mean }\end{array}$} & \multicolumn{2}{|c|}{$\begin{array}{l}95 \% \text { Confidence } \\
\text { Interval of the } \\
\text { Difference }\end{array}$} & & & \\
\hline & & & & Lower & Upper & & & \\
\hline $\begin{array}{l}\text { Pre- } \\
\text { test }\end{array}$ & $\begin{array}{r}-1.0 \\
370\end{array}$ & 1.675 & & -1.699 & -.3743 & -3. & 2 & .00 \\
\hline $\begin{array}{r}\text { Post- } \\
\text { test }\end{array}$ & $\begin{array}{r}370 \\
4\end{array}$ & 19 & .32239 & 72 & 5 & $\begin{array}{r}21 \\
7\end{array}$ & 6 & 3 \\
\hline
\end{tabular}


Based on Table 1 and 2, the pre-test yielded a value of $\mathrm{M}=5.59, \mathrm{SD}=3.38$ while the post-test score showed that higher value of $\mathrm{M}=6.63$ and $\mathrm{SD}=3.62$. Preceding the analysis, a normally distributed score was assumed. The skew and kurtosis levels were considered satisfied at -.15 and -.92 (George \& Mallery ${ }^{[16]}$ ) within the range of acceptable values for asymmetry and kurtosis (between -2 and +2 ) in proving normal univariate distribution.

In this study, the dependent sample t-test is also considered appropriate as the correlation between the preand post-test was estimated at $\mathrm{r}=.89, \mathrm{p}<0.01$. The post-test mean was significantly higher than the pre-test mean. Thus, the null hypothesis of equal mean between pre- and post-test was rejected, $\mathrm{t}(26)=-3.22, \mathrm{p}<0.01$. At 0.3 , Cohen's $\mathrm{d}$ was estimated as a small effect ${ }^{[12]}$.

\section{B. Pupils' Perception on the Use of Tarsia Puzzle in Learning Vocabularies}

The basic statistics and pupils' responses were as below:

Table 3: Pupils' Perception on using Tarsia Puzzle

\begin{tabular}{llcc}
\hline No & Question & Responses & Percentage \\
\hline $\mathbf{1}$ & $\begin{array}{l}\text { Did you enjoy } \\
\text { learning vocabulary } \\
\text { using Tarsia Puzzle? }\end{array}$ & Yes & $96 \%$ \\
\end{tabular}

In Table 3, majority of the participants agreed that Tarsia Puzzle was fun and entertaining. When probed further, pupils' responses can be categorised into several emerging themes.

Table 4: Why Pupils Enjoy Learning Vocabulary Using Tarsia Puzzle?

\begin{tabular}{lc}
\hline Reason & Percentage \\
\hline Collaboration & $19 \%$ \\
Effective study aid & $15 \%$ \\
Fun and Easy & $54 \%$ \\
Challenging & $15 \%$ \\
*Difficult (Don't enjoy the activity) & $4 \%$ \\
\hline
\end{tabular}

Based on Table 4, 19\% pupils responded that they enjoyed solving the puzzle with their friends. $15 \%$ noted that the puzzle was an accommodating study aid. 54\% pupils enjoyed playing with Tarsia puzzle as it was easily executed. Another $15 \%$ admitted that the activity was challenging for them. However, $4 \%$ pupil did not enjoy the activity. They claimed that "it is difficult."
Table 5: Significance of Tarsia Puzzle to Vocabulary Learning

\begin{tabular}{llcc}
\hline No & Question & Responses & Percentage \\
\hline 2 & $\begin{array}{l}\text { Does this activity help } \\
\text { you in remembering the }\end{array}$ & Yes & $70 \%$ \\
& $\begin{array}{l}\text { meaning of vocabulary } \\
\text { and how to use it in a } \\
\text { sentence? }\end{array}$ & & $30 \%$ \\
\end{tabular}

Most pupils (70\%) agreed that Tarsia Puzzle helped them in learning the form, meaning and use of the vocabulary dimension. However, $30 \%$ of the pupils responded that they could not remember the vocabulary items learnt. The responses include:

1. "there were so many vocabulary items to memorise"

2. "memorising is difficult"

Table 6: Effect of Using Tarsia Puzzle in Learning Vocabulary

\begin{tabular}{llcc}
\hline No & Question & Responses & Percentage \\
\hline 3 & $\begin{array}{l}\text { Are you more confident } \\
\text { now in using the }\end{array}$ & Yes & $37 \%$ \\
& $\begin{array}{l}\text { vocabulary items as } \\
\text { compared to before? }\end{array}$ & No & $37 \%$ \\
\hline
\end{tabular}

The pupils' responses varied to almost equal distributions. From Table 6, it can be seen $37 \%$ pupils thought that the activity boosted their confidence in using the vocabulary items learnt. $37 \%$ were still not confident in using the vocabulary items and the remaining $26 \%$ neither agreed nor disagreed.

Table 7: Difficulties Encountered by Pupils throughout the Activity

\begin{tabular}{|c|c|c|c|}
\hline No & Question & Responses & Percentage \\
\hline \multirow[t]{5}{*}{4} & \multirow{5}{*}{$\begin{array}{l}\text { Which part } \\
\text { of the } \\
\text { activity is } \\
\text { difficult for } \\
\text { you to } \\
\text { understand } \\
\text { or do? } \\
\text { Please } \\
\text { explain. }\end{array}$} & $\begin{array}{l}\text { Puzzle } 2 \text { (Verb use in a } \\
\text { sentence) }\end{array}$ & $41 \%$ \\
\hline & & Everything & $15 \%$ \\
\hline & & $\begin{array}{l}\text { Copying Verbs from the } \\
\text { Puzzle }\end{array}$ & $7 \%$ \\
\hline & & Looking up for meaning & $7 \%$ \\
\hline & & None & $30 \%$ \\
\hline
\end{tabular}

In Table 7, 41\% pupils responded that the second puzzle was more difficult than the first. $15 \%$ stated that all phases in the activity were difficult. $7 \%$ were concerned with writing task and looking for meaning of vocabulary from the 
dictionary (7\%). However, the majority $30 \%$ did not encounter any difficulty throughout the activity.

\section{DISSCUSSIONS \& CONCLUSION}

The pre- and post-test scores showed statistically significant difference, implying the pupils' vocabulary learning was affected positively. The pupils' answer also displayed evidence of vocabulary retention. They were able to use verbs present in the puzzle correctly in the post-test. In this study, the majority of participants (96\%) enjoyed learning vocabulary using Tarsia puzzle. Responses gathered from the participants varied based on their interest and language competence. Pupils responding to the level of difficulty (easy or challenging) were found to enjoy playing various types of puzzle. Solving Tarsia puzzle offered a sense of achievement among the young ESL learners. This corresponds to Jelle ${ }^{[23]}$ and Klymchuk ${ }^{[25]}$ statement pointing out how PBL drives motivation. A few participants actually enjoyed playing Tarsia because they noted the connection of the puzzle to their study and were concerned of their performance in English. Others enjoyed solving the puzzle as they managed to collaborate in their groups. This was specified by Stoten ${ }^{[42]}$ as one of the benefits of playing Tarsia puzzle. It was however not an enjoyable experience for one particular participant who found the game difficult.

$70 \%$ of participants acknowledged that the learning tool helped them in memorizing the meaning of the verb. Tarsia puzzle promotes intentional vocabulary acquisition when used in context to teaching language. Most of the participants regarded playing the puzzle as a learning activity instead of playing it for fun. The remaining participants disagreed that Tarsia puzzle helped them in vocabulary retention. Some commented that there were so many vocabulary items presented it was difficult for them to remember everything. On another note, Tarsia did not manage to exert significant effect in enhancing pupils' motivation to use the vocabulary items. One third of the participants admitted that they were still unsure on how to use the items and another one third did not think that Tarsia puzzle affected their motivation and confidence to use what they have learnt. This becomes a concern as the vocabulary items picked up during the activity will only reside as receptive vocabulary to them. The learners may not use it all in their writing. Although there were evidence of vocabulary retention in the post-test, the number of vocabulary items used from the puzzle was limited.

Various responses were gathered about the difficulties faced by pupils as the study was carried out. The pupils reported to having troubles mostly in solving the second puzzle (concerns on use). It was expected that applying knowledge in context could be a challenge for the pupils. A few stated that all the phases in the activity were difficult for them. Solving puzzle in group was ineffective in building personalized experience. The other participants had difficulties in copying the verbs from the puzzle and looking for meaning from the dictionary. The two processes were a subcomponent of reviewing the items in promoting Reflective Observation (RO). The lower proficiency pupils were struggling to complete the task as compared to the others as the sessions were limited to certain period.

The major outcome of this study suggests that Tarsia puzzle was effective in teaching vocabulary among young language learners. It may not be the conventional puzzle used in teaching English, yet it proved to be of significance. The present study lends support to Stoten's ${ }^{[42]}$ claim that Tarsia puzzle can be used to consolidate knowledge. The learners' perception on the learning tool was also found to be encouraging. Tarsia puzzle promotes a fun, collaborative learning environment, but also challenging in helping the pupils to test their knowledge. The present study has proposed an alternative for teachers in teaching vocabulary among the young ESL learners.

\section{REFERENCES}

[1]Ahmad, J. (2012). Intentional vs. incidental vocabulary learning. ELT Research Journal, 1(1), 71-79.

[2] Alghamdi, E. A. (2016). Untangling multimedia effects on EFL incidental vocabulary learning via playing an online hidden-object game. International Journal of Computer-Assisted Language Learning and Teaching (IJCALLT), 6(1), 24-39.

[3] Alizadeh, I. (2016). Vocabulary teaching techniques: A Review of common practices. International journal of research in English education, 1(1), 22-30.

[4]Alqahtani, M. (2015). The Importance of Vocabulary in Language Learning and How to be Taught. International Journal of Teaching and Education, 3(3), 21-34.

[5]Barcroft, J., Schmitt, N., \& Sunderman, G. (2011). Lexis. In J. Simpson (Ed.), The Routledge Handbook of Applied Linguistics. Abingdon, UK / New York: Routledge.

[6]Baskin, S., Iscan, A., Karagoz, B., \& Birol, G. (2017). The Use of Vocabulary Learning Strategies in Teaching Turkish as a Second Language. Journal of Education and Practice, 8(9), 126-134

[7]Becky, L., S. \& Susie, S.L. (2010). Puzzles-Toys...or teaching tools?. Super Duper Publications. Retrieved from https://www.superduperinc.com/handouts/pdf/245_Puzzles.pdf

[8]Burns, A. (2010). Doing action research in English Language Teaching: A guide for practitioners. New York: Taylor \& Francis

[9]Cheimonidou, P. (2016). Incidental and Intentional Vocabulary Acquisition through Storytelling: A Case study of Young Learners (Doctoral dissertation, Aristotle University of Thessaloniki).

[10] Cervatiuc, A. (2018). Incidental Learning of Vocabulary. The TESOL Encyclopedia of English Language Teaching, 1-6.

[11] Choi, J., Lee, Y., \& Lee, E. (2017). Puzzle based algorithm learning for cultivating computational thinking. Wireless Personal Communications, 93(1), 131-145.

[12] Cohen, J. (1988). Statistical power analysis for the behavioral sciences (2nd ed.). Hillsdale, NJ: Lawrence Earlbaum Associates.

[13] Elgort, I. (2011). Deliberate learning and vocabulary acquisition in a second language. Language Learning, 61(2), 367-413. http://dx.doi.org/10.1111/j.1467-9922.2010.00613.x

[14] Farlex, (2009). The Online Free Dictionary. Retrieved 28 December 2018 from http://www.thefreedictionary.com

[15] Falkner N, Sooriamurthi R, Michalewicz Z. Teaching puzzle-based learning: development of basic concepts. Teach Math Comput Sci. 2012;10(1):183-204. 
[16] Fernández, R. F., Prahlad, S. R. R., Rubtsova, E., \& Sabitov, O. (2009). Collocations in the vocabulary English teaching as a foreign language. Acimed, 19(6), 1-5.

[17] Franklin, S., Peat, M., \& Lewis, A. (2003). "Nontraditional interventions to stimulate discussion: The use of games and puzzles." Journal of Biological Education, 37 (2), pp. 79 - 84.

[18] George, D. \& Mallery, M. (2010). SPSS for Windows Step by Step: A Simple Guide and Reference, 17.0 update (10a ed.) Boston: Pearson.

[19] Goh, T. \& Hooper, V. (2007). "To TxT or Not to TxT: That's the Puzzle." The Journal of Information Technology Education, Vol. 6, pp. $441-453$.

[20] Hulstijn, J. H., \& Laufer, B. (2001). Some empirical evidence for the involvement load hypothesis in vocabulary acquisition. Language Learning, 51, 539 - 558.

[21] Hulstijn, J. H. (2003). Incidental and intentional learning. In C. J. Doughty, \& M. H. Long (Eds.), The Handbook of Second Language Acquisition (pp. 349-381). Malden, MA: Blackwell. http://dx.doi.org/10.1002/9780470756492.ch12

[22] Jaramillo, C. M. Z., Losada, B. M., \& Fekula, M. J. (2012). Designing and solving crossword puzzles: Examining efficacy in a classroom exercise. In Developments in Business Simulation and Experiential Learning: Proceedings of the Annual ABSEL conference (Vol. 39).

[23] Jelle, B. P. (2017). Reviewing the Learning Process through Creative Puzzle Solving. Creative Education, 2017, 8, 2009-2035

[24] Kim, S. (2008). What is a puzzle. In Game Design Workshop: A Playcentric Approach to Creating Innovative Games (pp. 35-39).

[25] Klymchuk, Sergiy. "Puzzle-based learning in engineering mathematics: students' attitudes." International Journal of Mathematical Education in Science and Technology 48, no. 7 (2017): 1106-1119.

[26] Kolb, David A. 1984. Experiential Learning: Experience as the Source of Learning and Development. Prentice-Hall, Inc., Englewood Cliffs, N.J.

[27] Kolb, A. Y., \& Kolb, D. A. (2017). Experiential learning theory as a guide for experiential educators in higher education. ELTHE: A Journal for Engaged Educators, 1(1), 7-14.

[28] McNiff, J. (2009). You and your action research project. Routledge.

[29] McNiff, J. (2013). Action research: Principles and practice. Routledge.

[30] Merrick, K. E. (2010). An empirical evaluation of puzzle-based learning as an interest approach for teaching introductory computer science. IEEE Transactions on Education, 53(4), 677-680.

[31] Michalewicz, Z., \& Michalewicz, M. (2008). Puzzle-based learning. Hybrid Publishers.

[32] Michalewicz, Z., Falkner, N., \& Sooriamurthi, R. (2011). Puzzle-based learning: An introduction to critical thinking and problem solving. decision line, 42(5), 6-9.

[33] Nation, I. S. P. (1990). Teaching and learning vocabulary. Boston, Mass: Heinle \& Heinle Publishers.

[34] Nation, I. S. P. (2001). Learning vocabulary in another language. Cambridge: Cambridge University Press

[35] Njoroge, M. C., Ndung'u, R., \& Gathigia, M. G. (2013). The use of crossword puzzles as a vocabulary learning strategy: A case of English as a second language in Kenyan secondary schools. International Journal of Current Research, 5(2), 313-321.

[36] Orawiwatnakul, W. (2013). Crossword puzzles as a learning tool for vocabulary development. Electronic Journal of Research in Educational Psychology, 11(2), 413-428

[37] Patel, JR, \& Dave, DJ. Implementation and evaluation of puzzle-based learning in first MBBS students. Natl J Physiol Pharm Pharmacol 2019;9(6):519-523.

[38] Read, J. (2004). Research in teaching vocabulary. Annual Review of Applied Linguistics, 24, 146-61.

[39] Richards, J., \& Schmidt, R. (2002). Longman dictionary of language teaching and applied linguistics. Malaysia: Pearson Education.

[40] Saxena, A., Nesbitt, R., Pahwa, P., \& Mills, S. (2009). Crossword puzzles: active learning in undergraduate pathology and medical education. Archives of pathology \& laboratory medicine, 133(9), $1457-1462$
[41] Schmitt, N. (2008). Teaching vocabulary. White Plains, NY: Pearson Education.

[42] Stoten, D. W. (2017). Tarsia: An Interactive and Engaging Activity That Promotes Consolidation of Knowledge. Management Teaching Review, 2(3), 225-234

[43] Weisskireh, R.S. (2006). "An analysis of instructorcreated crossword puzzles for student review." College Teaching, 54(1), pp. 198-201.

[44] Whisenand, T. G., \& Dunphy, S. M. (2010). Teaching Tip: Accelerating Student Learning of Technology Terms: The Crossword Puzzle Exercise. Journal of Information Systems Education, 21(2), 141.

[45] Wilkins, D. (1972). Linguistics in language teaching. London, UK: Arnold.

[46] Zandieh, Z., \& Jafarigohar, M. (2012). The Effects of Hypertext Gloss on Comprehension and Vocabulary Retention under Incidental and Intentional Learning Conditions. English Language Teaching, 5(6), $60-71$

Wan Shafika Omar is currently teaching in a primary school in Malaysia. Her research interests include practice-based research and educational inquiry which concerns the young ESL learners.

Nur Ehsan Mohd Said is a lecturer at the Faculty of Education, National University of Malaysia, who began his career in the academia in 2009. He obtained his PHD in English Language and Linguistics from the University of Sheffield, UK. His primary research interests lie in the area of classroom research and intervention studies, differentiated module development, and English for specific purposes. 